\title{
TRANSPORT TECHNOLOGY AND ECONOMIC EXPANSION: THE GROWTH CONTRIBUTION OF RAILWAYS IN LATIN AMERICA BEFORE 1914*
}

\author{
ALFONSO HERRANZ-LONCÁN \\ University of Barcelona ${ }^{\text {a }}$
}

\begin{abstract}
This paper measures the direct contribution of railways to economic growth before 1914 in four Latin American economies with large railway systems (Argentina, Brazil, Mexico and Uruguay) using growth accounting techniques. The outcomes of the analysis indicate that the growth contribution of railways in Uruguay was very low. By contrast, in Argentina and Mexico railways provided huge benefits, amounting to $20-25 \%$ of income per capita growth before 1914. Finally, in Brazil, the growth contribution of railways was even higher, although this was largely a consequence of the stagnation of the Brazilian economy. These results provide an example of a technology whose growth contribution was much higher in some peripheral economies than in the core countries where it was developed.
\end{abstract}

Keywords: growth accounting, Latin America, economic growth, first globalisation, railways

JEL Code: N16, N76, O40, R40

* Received 26 March 2013. Accepted 3 October 2013. This research has been financed by the Spanish Ministry of Science and Innovation project ECO2012-39169-C03-03. I thank Sandra Kuntz, Paolo Riguzzi and the participants at the I Encuentro de la AEHE, the XXVI Jornadas of the Banco Central del Uruguay, the 2011 Carlos III FRESH Meeting and the 9th EHES Conference for their comments and help. They are not responsible for any mistakes in the paper.

a Department of Economic History and Institutions, Diagonal, 690; 08034 Barcelona, Spain. alfonso.herranz@ub.edu 


\section{RESUMEN}

En este artículo se estima, aplicando las técnicas de contabilidad del crecimiento, la contribución directa de los ferrocarriles al crecimiento económico, antes de 1914, de cuatro economías latinoamericanas con sistemas ferroviarios muy desarrollados (Argentina, Brasil, México y Uruguay). Los resultados del análisis indican que la contribución directa de los ferrocarriles al crecimiento económico uruguayo fue muy baja. En cambio, los ferrocarriles proporcionaron a Argentina y México unos beneficios directos de enorme magnitud, que representaron entre el $20 \%$ y el $25 \%$ del crecimiento de la renta per cápita de esos países antes de 1914. Finalmente, la contribución de los ferrocarriles brasileños al crecimiento económico fue todavía mayor, aunque ello fue en gran medida consecuencia del estancamiento de la economía brasileña. Estos resultados ofrecen un ejemplo de una tecnología cuya contribución al crecimiento fue mucho mayor en algunas economías periféricas que en los países industrializados en los que esa tecnología se desarrolló.

Palabras clave: Contabilidad del crecimiento, América Latina, Crecimiento económico, Primera Globalización, Ferrocarril

\section{INTRODUCTION}

Between the mid- $19^{\text {th }}$ century and the eve of the Great War, Latin America had one of the fastest rates of economic growth in the world. According to Maddison's (2001) figures, the economies of the area grew well above the world average between 1870 and 1913, with a growth rate comparable with that of the "Western Offshoots». This growth episode was largely a consequence of the expansion of exports of primary products during the first globalisation boom.

Railways were one of the main growth engines of Latin American economies during the period, and their potential impact was probably more important in that region than in the Western European countries where railway technology had been developed. Due to the low quality of the previous transport infrastructures and the scarcity of waterways in the region in the mid- $19^{\text {th }}$ century, in many countries railways constituted the only available means to integrate domestic markets and to connect them with the international economy. This was especially critical in a period, such as the first globalisation, in which the expansion of Latin American economies was largely based on exports of natural resources and, therefore, depended crucially on the availability of efficient transport means throughout as much of their territory as possible. Railways were less indispensable in those areas better endowed with waterways, such as the Amazonas basin in Brazil, the 
TABLE 1

AVAILABLE ESTIMATES OF SOCIAL SAVINGS OF FREIGHT RAILWAY TRANSPORT IN SEVERAL COUNTRIES

\begin{tabular}{|l|c|c|}
\hline & Year & Social savings/GNP or GDP (\%) \\
\hline United States & 1859 & 3.7 \\
\hline United States & 1890 & 4.7 \\
\hline England and Wales & 1865 & 4.1 \\
\hline Russia & 1907 & 4.5 \\
\hline France & 1872 & 5.8 \\
\hline Spain & 1878 & 4.4 \\
\hline Spain & 1912 & 12.7 \\
\hline Brazil & 1913 & $18.0 / 38.0$ \\
\hline Mexico & 1910 & $24.9 / 38.5$ \\
\hline Argentina & 1913 & 20.6 \\
\hline Uruguay & $1912-1913$ & 3.8 \\
\hline Colombia & 1927 & $3.4 / 7.9$ \\
\hline Peru & 1914 & $3.7 / 6.7$ \\
\hline
\end{tabular}

Sources: Fishlow (1965, pp. 37, 52); Fogel (1964, p. 223); Hawke (1970, p. 196); Metzer (1977, p. 50); Caron (1983, p. 44); Herranz-Loncán (2008, p. 140); Summerhill (2003, p. 89); Coatsworth (1979, p. 952); Herranz-Loncán (2011a, p. 40); Herranz-Loncán (2011b, p. 13); Ramírez (2001, p. 89); Zegarra (2013, p. 55).

Magdalena River area in Colombia or the River Plate system in Uruguay and north-east Argentina, or in those few cases, such as Chile, in which coastal transport could be used to move goods around the country. However, apart from these cases, in most economies railways constituted a necessary condition for domestic integration and the take-off of many export productions. This indispensability has led Summerhill (2006, p. 297) to suggest that: «it seems unlikely that any other technological or institutional innovation was more important in the transition to economic growth in Latin America before 1930 ».

The crucial role of Latin American railways before 1914 has been confirmed, for some countries, by the social saving literature (see Table 1). In Argentina (Summerhill 2000; Herranz-Loncán 2011a), Mexico (Coatsworth 1979) and Brazil (Summerhill 2003), due to the lack of cheap transport alternatives, railways provided social savings amounting on average to about one-quarter of total GDP by 1910-1913. Among those countries that built extensive railway networks before 1914, social savings were only relatively 
low in Uruguay (Herranz-Loncán 2011b), because the geography of this country provided it with exceptional natural transport advantages, which made railways less indispensable. Social savings were also low in Colombia and Peru, but in these cases it was largely due to the smaller size of the railway network and the relatively low development of railway transport services (Ramírez 2001; Zegarra 2013).

In fact, with the exception of Uruguay, in countries that built large railway networks a substantial proportion of GDP per capita growth can be directly explained by the development of the railway sector. According to the basic growth accounting identity, income per capita growth can be divided into increases in physical capital stock per capita and «crude» total factor productivity (TFP) growth (the so-called «Solow residual»). In countries with large railway networks, railway capital accounted for a substantial share of the gross capital formation during the first globalisation, and a large part of TFP growth took place in the transportation sector, thanks to the introduction and improvement of railway technology. The aim of this paper is to measure the direct contribution of railways to economic growth in four Latin American economies with large railway systems (Argentina, Brazil, Mexico and Uruguay), in order to illustrate the central position of the railway transport sector in the economic evolution of these countries before 1914 .

This research derives from previous similar work by Crafts (2004b) for Britain and Herranz-Loncán (2006) for Spain. My results confirm that the railway sector directly accounted for a much larger proportion of income per capita growth in Argentina, Brazil and Mexico than in Spain or Britain. By contrast, in Uruguay, despite the relatively large size of the network, the growth contribution of railways remained tiny, due to the sluggish development of railway output and the transport advantages that the country enjoyed before the railway era.

\section{RAILWAYS IN LATIN AMERICA}

By 1914 railways were present all over Latin America, although their development varied hugely from one country to another. The first railway line in the region was opened in Cuba in 1837, only 12 years after the inauguration of the first British railway. Cuba was not joined by any other Latin American economy until the 1850s, when railway construction gradually took off in Argentina, Brazil, Chile, Colombia, Costa Rica, Mexico and Peru. By 1900, all countries of the region had some railways in operation. Railway construction was especially intense in Argentina, Brazil and Mexico. These countries accounted, since the late 1880s, for $\sim 75$ per cent of the whole Latin American railway mileage. However, in terms of railway density (railway mileage per square $\mathrm{km}$ ), they fell behind some small Central American and Caribbean countries, as may be seen in Table 2, 
TABLE 2

RAILWAY MILEAGE IN LATIN AMERICA IN 1912

\begin{tabular}{|l|c|l|c|l|c|}
\hline & $\begin{array}{c}\text { Total length } \\
\mathbf{( k m )}\end{array}$ & & $\begin{array}{c}\mathbf{k m} / \\
\mathbf{1 0 , 0 0 0} \mathbf{k m}^{\mathbf{2}}\end{array}$ & & $\begin{array}{c}\mathbf{k m} / \mathbf{1 , 0 0 0} \\
\mathbf{p o p} .\end{array}$ \\
\hline Argentina & 32,212 & Puerto Rico & 388.84 & Argentina & 4.49 \\
\hline Brazil & 23,491 & Cuba & 333.72 & Chile & 2.19 \\
\hline Mexico & 20,447 & Salvador & 154.44 & Uruguay & 2.19 \\
\hline Chile & 7,260 & Uruguay & 135.24 & Costa Rica & 1.57 \\
\hline Cuba & 3,803 & Costa Rica & 119.50 & Cuba & 1.46 \\
\hline Peru & 3,276 & Argentina & 113.89 & Mexico & 1.27 \\
\hline Uruguay & 2,522 & Chile & 109.71 & Brazil & 0.94 \\
\hline Bolivia & 1,284 & Mexico & 103.74 & Peru & 0.83 \\
\hline Colombia & 1,061 & Guatemala & 74.28 & Bolivia & 0.80 \\
\hline Venezuela & 858 & Dominican R. & 48.97 & Paraguay & 0.52 \\
\hline Guatemala & 808 & Haiti & 36.15 & Guatemala & 0.49 \\
\hline Costa Rica & 619 & Brazil & 27.60 & Puerto Rico & 0.46 \\
\hline Ecuador & 587 & Nicaragua & 24.86 & Nicaragua & 0.46 \\
\hline Paraguay & 373 & Paraguay & 23.23 & Honduras & 0.38 \\
\hline Puerto Rico & 354 & Peru & 23.08 & Venezuela & 0.35 \\
\hline Nicaragua & 322 & Ecuador & 20.60 & Ecuador & 0.32 \\
\hline El Salvador & 320 & Honduras & 15.26 & Dominican R. & 0.31 \\
\hline Dominican R. & 241 & Colombia & 10.34 & Salvador & 0.29 \\
\hline Honduras & 170 & Panama & 10.12 & Panama & 0.21 \\
\hline Haiti & 103 & Bolivia & 9.93 & Colombia & 0.17 \\
\hline Panama & 76 & Venezuela & 9.41 & Haiti & 0.10 \\
\hline Total & 100,187 & Weighted av. & 50.44 & Weighted av. & 1.29 \\
\hline & & & & & \\
\hline
\end{tabular}

Sources: Railway data from Mitchell (2003) and Sanz Fernández (1998), except in the following cases: Argentina (from Dirección General de Ferrocarriles, Estadística de los Ferrocarriles en Explotación, 1892-1913); Chile before 1870 (own estimation from Marín Vicuña, 1901 and Alliende Edwards, 1993); and Uruguay (own estimation from the country's statistical yearbooks). Population figures come from Yáñez et al. (2012), except for Bolivia, which have been taken from Herranz-Loncán and Peres-Cajías (2013). 
due to their large surface area and the low settlement rates of some parts of their territory.

Table 2 may be taken as preliminary evidence of the different role that railways performed in each Latin American economy before 1914. In both tables, Argentina stands out as a special case, where railway expansion reached levels comparable to some European networks. Other economies in which relatively large and dense networks were constructed were Uruguay, Chile, Cuba, Mexico and Brazil. By contrast, in the rest of the continent railway development was slower and railway systems were scarcely integrated, often consisting of a few isolated lines that connected production areas with the main ports and hardly affected large areas of their countries.

This paper focuses on the cases of Argentina, Brazil, Mexico and Uruguay (from now on, LA4), a sample of countries that, according to Maddison's database, accounted for 65 per cent of Latin American GDP and 59 per cent of the region's population in 1913. These countries occupy the first places in Table 2; they possessed 79 per cent of total Latin American railway mileage in 1912 and had, together with Chile, Costa Rica and Cuba, the highest mileage per capita in the region. Actually, with the exception of Brazil, they were among the few Latin American countries to build integrated national railway networks.

These countries had widely different economic experiences during the first globalisation. Argentina and Uruguay were probably the economies with highest income per capita and human development levels in Latin America before 1913, and grew very rapidly throughout the period (especially Argentina) on the basis of an impressive export boom and a huge inflow of migrant population. In both cases, animal products (such as wool, hides and skin and beef) represented a high share of the total exports during most of the period, although in Argentina wheat and maize exports quickly gained relevance from the late- $19^{\text {th }}$ century. This was only possible thanks to the availability of railway transport in the Pampas (Cortés Conde 1979, pp. 81-90). Economic growth was slower in Mexico and, especially, in Brazil, which was virtually stagnant during a large part of the first globalisation period. The disappointing behaviour of the Brazilian economy was largely associated with the economic stagnation of some of the country's regions, such as the north-east or Rio de Janeiro, and was compatible with the high dynamism of other areas, such as São Paulo. The latter was based on the boom in coffee exports (also made possible, beyond a certain distance from the sea, by the railways) and European immigration, and constituted the basis for an incipient industrialisation process. Finally, the Mexican economy, despite having also remained virtually stagnant before the late 1870s, undertook a substantial growth process during the Porfiriato (1876-1910), which was largely based on the expansion of silver exports and US capital and import demand, but also on the dynamism of domestic markets and a very early process of state-led industrialisation (Bértola and Ocampo 2010). 
As in Argentina and Brazil, the growth of both exports and domestic trade was also possible in Mexico, to a large extent, thanks to railways (Kuntz Ficker 1995).

A priori, due to the extension of the railway networks of these four countries, they might be expected to be among those Latin American economies in which the growth contribution of the railway sector was higher. Actually, with the exception of Uruguay, historians have often insisted in the importance of railways for these countries' economic growth. For instance, according to Summerhill (2003), "the railroad conferred on Brazil benefits that probably exceeded, by far, those stemming from the other major changes in economic organization in this period» (p. 96), and railways may be considered to have «laid the groundwork for Brazil's transition to rapid economic growth after 1900»(p. 1). In the case of Argentina:

"[i]n the aggregate, railroad technology accounted for an appreciable portion of the productivity growth enjoyed by the Argentine economy between 1890 and 1913. Railroads were certainly not the sole determinant of overall gains in productivity in the economy, but they were no doubt among the most important» ${ }^{1}$.

And, in Mexico, railways «were one of the most powerful factors of transition to capitalism» ${ }^{2}$. The next sections try to approach the share of income per capita growth of these countries that may directly be accounted for by railways through the application of growth accounting techniques.

\section{THE MEASUREMENT OF THE GROWTH CONTRIBUTION OF RAILWAYS}

The starting point to measure the growth contribution of a new technology is the usual Solow expression for increases in labour productivity:

$$
\Delta(Y / L) /(Y / L)=s_{K} \Delta(K / L) /(K / L)+\Delta A / A
$$

where $Y$ is total output, $L$ is the total number of hours worked, $K$ denotes the services provided by the physical capital stock, $A$ is «crude» TFP, and $s_{K}$ is the factor income share of physical capital. This expression has been used by recent research as a basis for approaching the contribution of some general purpose technologies to productivity growth. Oliner and Sichel (2002), for instance, apply a disaggregated version of the expression in which different types of capital and different components of TFP growth are distinguished. This allows them to measure the growth contribution of information and

\footnotetext{
1 Summerhill (2000, p. 5); see also Lewis (1983, p. 220).

2 Kuntz Ficker (1999, p. 134); see also Kuntz Ficker (1995) and Dobado and Marrero (2005).
} 
communication technologies (ICT), both through disembodied TFP growth and through the embodied capital-deepening effect of investment in those technologies. Therefore, they transform expression [1] into

$$
\begin{aligned}
\Delta(Y / L) /(Y / L)= & s_{K_{o}} \Delta\left(K_{o} / L\right) /\left(K_{o} / L\right)+\gamma(\Delta A / A)_{o}+s_{\mathrm{KICT}} \Delta\left(K_{\mathrm{ICT}} / L\right) /\left(K_{\mathrm{ICT}} / L\right) \\
& +\varphi(\Delta A / A)_{\mathrm{ICT}}
\end{aligned}
$$

where $K_{\mathrm{ICT}}$ and $K_{O}$ are the services provided by capital stock in ICT (or any other new technology) and in other sectors, respectively, $A$ is the TFP level in the sector indicated by the subscript (ICT and other), $s_{\mathrm{KICT}}$ and $s_{K_{o}}$ are the factor income shares of the capital invested in ICT and other capital, and $\varphi$ and $\gamma$ are the shares of ICT and other sectors' production in total output. The growth contribution of ICT (or any other new technology) may be approached by the sum of the last two terms of equation [2], which would approach, respectively, the "capital term» and the «TFP term» of that growth contribution.

Actually, if we want to measure the whole contribution of a new technology to economic growth through TFP increases, we must distinguish between two components of the TFP term. The first consists of TFP growth within the sector under consideration. The second is the increase in TFP associated with the substitution of that sector for the previous technology. In the case of advanced economies, the second component may be expected to be rather small, since new technologies are introduced early, when they still provide their services at similar costs to the old technology that they replace. For instance, in the case of Britain, railways were introduced when they could provide transport services at a similar unit cost to that of their competitors (mainly waterways and coastal navigation). In that case, the main component of the TFP term of the growth contribution of the railways would be associated with TFP increases within the railway sector itself.

By contrast, in the case of peripheral countries, which acquire new technologies from the core economies, the «TFP term» in expression [2] may be expected to be substantially higher than TFP growth in the sector under consideration for two reasons. On the one hand, the old sectors that the new technology replaces are probably less efficient than in the core economies. On the other hand, peripheral countries acquire the new technology when it has already been used and improved in the core economies for some years. As a consequence, at the time of the introduction of the new technology, the difference between the unit cost of its services and the unit cost of the services provided by the old technology may be very large. In a complete assessment of the growth contribution of a new technology, the TFP term should include this difference.

This issue was already stressed in Herranz-Loncán (2006) for the case of the Spanish railways. Whereas, as has already been indicated, the first British railways had no great cost advantage over their main competitor 
(i.e. water transportation) when they were established, the first Spanish railway services were considerably cheaper than the alternative modes they displaced (mainly traditional overland transportation) even at the beginning of the railway era, and the difference between railway and traditional transport costs should be included in the TFP term (and added to the last term of expression [2]). Similarly, an estimate of the whole TFP increase associated with Latin American railways should not only include TFP improvements within the railway sector (as in the British case), but also those TFP gains that were associated with the shift from old forms of transportation to the railways (as in the Spanish case).

To that end, instead of approaching the TFP term of expression [2] through TFP growth in the railway sector over the period under consideration, it may be estimated by comparing railway transport costs at the end of the period with the cost of domestic transportation just before the introduction of railways in the economy. This exercise is actually similar to measuring the social savings of railways, which are usually calculated as

$$
S S=\left(P_{\mathrm{TR}}-P_{\mathrm{RW}}\right) \times Q_{\mathrm{RW}}
$$

where $P_{\mathrm{RW}}$ and $P_{\mathrm{TR}}$ are, respectively, the price of railway and traditional (pre-railway) transport, and $Q_{\mathrm{RW}}$ is the railway transport output in the reference year ${ }^{3}$.

The social saving expression [3] is actually an upward-biased estimate (due to the implicit assumption of a price-inelastic transport demand) of the equivalent variation consumer surplus provided by the railways. If perfect competition in the rest of the economy is assumed, it provides a general equilibrium measure of the entire direct real income gain obtained from reducing resource cost in transportation (Metzer 1984; Jara-Díaz 1986). The price dual measure of TFP allows us to consider such gain in real income as equivalent to the TFP increase provided by the railways. However, the potential presence of imperfect competition or scale economies in the transport-using sectors makes this measure a lower bound estimate of the total income gain of the railways, due to the exclusion of the potential TFP spillovers, a problem that must be kept in mind in the interpretation of the results.

In a country like Britain, where railways were only introduced at the point where they could offer transport services at the same cost as water transportation, the social saving measure of the total income gain obtained by the economy from railways would be barely equivalent to TFP gains in the railway sector itself (Crafts 2004a, p. 6). By contrast, in the LA4 economies,

${ }^{3}$ In fact, the social savings calculation is, in principle, based on a comparison between railway rates and the prices that alternative transport means would have had if the railway system had been closed in the year of reference of the calculation, rather than their prices before the introduction of railways. Therefore, the social savings would only be representative of the TFP increase provided by railways under the assumption that there were no productivity improvements in the alternative transport means. This issue is developed in more detail below. 
TABLE 3

RAILWAYS' CONTRIBUTION TO GROWTH IN BRITAIN AND SPAIN BEFORE 1913

\begin{tabular}{|l|c|c|c|c|}
\hline & $\begin{array}{c}\text { Britain } \\
\mathbf{1 8 3 0}-\end{array}$ & $\begin{array}{c}\text { Britain } \\
\mathbf{1 8 5 0} \\
\mathbf{1 8 7 0}\end{array}$ & $\begin{array}{c}\text { Britain } \\
\mathbf{1 8 7 0 -} \\
\mathbf{1 9 1 0}\end{array}$ & $\begin{array}{c}\text { Spain } \\
\mathbf{1 8 5 0} \\
\mathbf{1 9 1 2}\end{array}$ \\
\hline (a) Railway capital stock per capita growth & 22.8 & 5.9 & 0.4 & 4.2 \\
\hline (b) Railway profits share in national income & 0.6 & 2.1 & 2.7 & 0.86 \\
\hline $\begin{array}{c}\text { (c) «Capital term» of the railway growth contri- } \\
\text { bution (a } \times \text { b) (percentage points per year) }\end{array}$ & 0.14 & 0.12 & 0.01 & 0.036 \\
\hline (d) Railway TFP growth & 1.9 & 3.5 & 1.0 & - \\
\hline (e) Railway share in national output & 1.0 & 4.0 & 6.0 & - \\
\hline $\begin{array}{c}\text { (f) «TFP term» of the railway growth contribution } \\
\text { (d } \times \text { e) (percentage points per year) }\end{array}$ & 0.02 & 0.14 & 0.06 & $\begin{array}{l}0.10 / \\
0.13^{1}\end{array}$ \\
\hline $\begin{array}{c}\text { (g) Total gain in real income from railway TFP } \\
\text { growth/Income per capita increase since the } \\
\text { beginning of the railway era (\%) }\end{array}$ & - & - & - & $10.01 /$ \\
\hline $\begin{array}{c}\text { (h) Total railway contribution (c }+ \text { f) (percentage } \\
\text { points per year) }\end{array}$ & 0.16 & 0.26 & 0.07 & $\begin{array}{c}0.14 / \\
0.17\end{array}$ \\
\hline $\begin{array}{c}\text { (i) Railway contribution as \% of GDP per } \\
\text { capita growth }\end{array}$ & 14.97 & 18.85 & 8.51 & $\begin{array}{c}13.64 / \\
16.19\end{array}$ \\
\hline
\end{tabular}

Note $:$ TFP $=$ total factor productivity.

${ }^{1}$ Calculated from row $g$ and the income per capita growth rate in 1850-1912.

${ }^{2}$ Calculated directly from the available social savings estimates.

Sources: Own elaboration from Crafts (2004b) and Herranz-Loncán (2006, 2008).

or in Spain, a large share of the total gain in real income (as measured from the social savings estimations) would consist of those TFP gains associated with the shift from old forms of transportation to railways.

Table 3 presents the available estimates of the share that railway technology accounted for within British and Spanish economic growth as the sum of the two last terms of expression [2]. In both countries, railway technology accounted on average for $\sim 13-16$ per cent of GDP per capita growth in the six/eight decades before 1913. This is indeed a substantial share for a single sector. However, the similarity between the estimates for both countries critically depends on the inclusion, in the Spanish case, of the resourcesaving effects of the shift from alternative transport modes to railways. If this shift were not considered, the Spanish railway share would only amount to $\sim 5$ to 6 per cent of Spanish GDP per capita growth, that is, less than half the percentage presented in Table $4^{4}$.

\footnotetext{
${ }^{4}$ The situation would be similar in the Indian case, according to Bogart and Chaudhary (2012).
} 
TABLE 4

GROWTH RATE OF RAILWAY MILEAGE PER CAPITA

\begin{tabular}{|l|c|c|}
\hline Country & Period considered & $\begin{array}{c}\text { Railway km per capita yearly } \\
\text { growth rate (\%) }\end{array}$ \\
\hline Argentina & $1865-1913$ & 6.36 \\
\hline Brazil & $1864-1913$ & 6.25 \\
\hline Mexico & $1873-1910$ & 8.61 \\
\hline Uruguay & $1874-1913$ & 3.91 \\
\hline
\end{tabular}

Note: Growth rates are estimated by adjusting a log-trend to the mileage data.

Sources: Railway mileage comes from Mitchell (2003), except for Uruguay, for which it has been directly estimated from the country's statistical yearbooks, and for Argentina (from Dirección General de Ferrocarriles, Estadística de los Ferrocarriles en Explotación, 1892-1913). Population has been taken, for Mexico and Brazil, from Maddison's database, for Uruguay, from Bértola (1998), and for Argentina, from Vázquez-Presedo (1971). Gaps in population data have been filled through geometric interpolation.

The relationship between the social savings and the growth accounting "TFP term» has been stressed by Crafts (2004a) and (2010) and Leunig (2010). Actually, it is implicit in some measurement exercises performed by Coatsworth (1981, pp. 116-117) for Mexico and by Summerhill (2003, p. 105) for Brazil, in which these authors compare their estimates of the freight social savings of railways with these countries' long-term gains in aggregate productivity. According to their calculations, the direct income gain associated with railway freight services would amount to 25 per cent of Mexican productivity growth between 1877 and 1910 and 19 to 66 per cent of the Brazilian productivity growth between 1885 and 1913 . However, as has been indicated, a complete assessment of the growth contribution of railways in these countries should also include the "capital term» (see expression [2])

This is related to the fact, that, unlike social saving estimations, growth accounting methodology is intended to measure the actual contribution of railways to economic growth, and not the net income difference between an economy with and without railways, which is the objective of the counterfactual exercise involved in the social savings. The latter excludes the "capital term», under the assumption that, in the absence of railways, the capital invested in the sector would have been addressed to a different destination with a similar return in the same country (Crafts 2004a, p. 7). However, this assumption is difficult to accept without further discussion in the case of Latin America due to the foreign origin of most railway capital and the prominence of railways in total foreign investment. It is plausible

${ }^{5}$ In addition, these authors' estimates do not include the (cost and time) benefits associated with passenger railway transport in both countries. 
that, in the absence of the railways, part of the resources invested in railway construction would have been devoted to improving the condition of alternative transport systems. However, due to the foreign origin of most railway capital, it is also likely that at least part of those resources would not have been transferred to the LA4 economies. Therefore, although it is not the objective of this research, it is important to stress that, in a complete counterfactual analysis of the economic impact of railways in those countries, it would be reasonable to include at least part of the capital term of the growth contribution measurement.

\section{THE GROWTH CONTRIBUTION OF RAILWAYS IN ARGENTINA, BRAZIL, MEXICO AND URUGUAY}

As has been described in the previous section, the growth contribution of railways may be estimated as the sum of two terms. The first is the product of the growth rate of the railway capital stock per capita times the factor income share of railway capital (the "capital term»). The second is the TFP growth rate in the transport sector (including TFP increases associated with the shift from alternative means to railways) times the share of railway production in total output (the "TFP term»). The next two subsections are devoted to the estimation of these two terms in the LA4 countries before 1914.

\subsection{The Contribution of Railways to Economic Growth: The Capital Term}

There are no available estimates of railway capital stock for the LA4 countries during the second-half of the $19^{\text {th }}$ century and the first few years of the $20^{\text {th }}$ century. Therefore, as is customary in this kind of exercises, I have assumed the evolution of railway capital to be similar to that of railway mileage ${ }^{6}$. Table 4 shows the yearly growth rates of railway mileage per capita in the LA4 countries from the start of the "railway era» until the eve of World War I $\mathrm{I}^{7}$. I have not included in the analysis the early years of railway operation when only a few short stretches with very little traffic and a minimum economic impact were open to the public. Therefore, I start my estimates, in

6 This assumption introduces a certain bias in the estimation of the capital term. The direction of this bias is unknown: the capital stock may grow faster than railway mileage due to increasing quality or complexity of the lines, but it can also grow more slowly, due to the incorporation of secondary (and cheaper) lines to the system. This was the case, for instance, in Spain between 1850 and 1912, when railway mileage increased at a yearly rate of 5.3 per cent, whereas the railway capital stock grew at a lower yearly rate of 4.7 per cent (Herranz-Loncán 2005).

${ }^{7}$ In the case of Mexico, I end the analysis in 1910 to avoid the impact of the Mexican revolution and to adapt my research to the chronology of Coatsworth's social saving estimation, which is the basis of my estimate of TFP growth in the transport sector (see below). 
the case of Argentina, in 1865 (when towns such as Luján, Mercedes and Chascomús were finally connected to Buenos Aires and there were already 213 railway $\mathrm{km}$ in operation), in the case of Brazil, in 1864 (year of the connection of Rio de Janeiro with the Vale do Paraíba via the Dom Pedro II railway, when 474 railway $\mathrm{km}$ were already open), in the case of Mexico, in 1873 (when the Mexico-Veracruz line was completed and there were $572 \mathrm{~km}$ of operating railways) and, in the case of Uruguay, in 1874 (when Montevideo was connected with Durazno, and the mileage in operation reached $279 \mathrm{~km})^{8}$.

In order to estimate the capital term of the growth contribution of railways in each country, those rates should be multiplied by the factor income shares of railway capital, that is, the average ratios between railway net operating revenues and nominal GDP throughout the period under consideration. Table 5 presents estimates of those ratios for the LA4 countries. These figures must be taken with certain caution, especially in the cases of Mexico and Brazil, mainly because of the uncertain quality of the available nominal GDP figures. Keeping this problem in mind, the figures clearly show the outstanding importance of the railway sector in Argentina, compared with the rest. Actually, the Argentinean ratio between net revenues and GDP was not very far away from the average British equivalent figure in 1850-1910 (2.52 per cent). By contrast, the corresponding ratio was significantly lower in Brazil, Mexico and Uruguay, where figures were closer to the equivalent Spanish figure in 1850-1912 (0.86 per cent). This provides a first indication of the different importance of the railway sector in export-led growth episodes during the period, and the prominent position of Argentinean railways in the economy, as stressed below.

Table 6 shows the product of the ratios in Table 5 times the growth rates of railway capital reported in Table 4. This would be equivalent to the «capital term» of the railway growth contribution, under the assumptions of constant returns to scale in the production of railway services and perfect competition both in the railway industry and in the rest of the economy, which would allow us to consider the ratio between net railway revenues and GDP as a good proxy for the output elasticity of capital in the railway industry. These assumptions are clearly too strict for a highly regulated sector such as

8 The choice of the starting year has a significant impact on the growth rates reported in Table 4, which decrease substantially when the starting date is moved forward. However, this impact is overcome by the increase in the average ratio between net railway revenues and nominal GDP (reported in Table 5), which was much lower in the first years of railway operation due to the low size of railway output. As a consequence, the net impact of a change of starting date in the final growth accounting estimates is very small. For instance, if the starting date of the analysis were moved 10 years forward in each country, the decrease in the «capital term» presented in Tables 6 and 12 would amount to 0.014 points of yearly growth in Argentina, 0.011 points in Brazil, 0.040 points in Mexico and no significant change in Uruguay. These reductions would represent between 0 and 8 per cent of the estimates of the total growth contribution of the railways presented in Table 12 . 
TABLE 5

AVERAGE RATIO BETWEEN NET RAILWAY REVENUES AND NOMINAL GDP IN LA4 DURING THE RAILWAY ERA

\begin{tabular}{|l|c|}
\hline & $\begin{array}{c}\text { Railway profit share in national income } \\
\text { (net railway revenues/GDP, \%) }\end{array}$ \\
\hline Argentina (1865-1913) & 1.81 \\
\hline Brazil (1864-1913) & 0.81 \\
\hline Mexico (1873-1910) & 0.91 \\
\hline Uruguay (1874-1913) & 0.71 \\
\hline
\end{tabular}

Sources and notes:

Argentina: Net revenue data from Dirección General de Ferrocarriles, Estadística de los ferrocarriles en explotación (1892-1913). Nominal GDP has been taken, for 1900 onwards, from the Moxlad database. For 1875-1900, I have driven backwards the Moxlad estimates on the basis of the evolution of real GDP, taken from Della Paolera et al. (2003), and price indices, taken, for 1884-1900, from Della Paolera et al. (2003), and, for 1875-1884, from Ferreres (2005). For 1865-75 I have estimated nominal GDP on the basis of Prados de la Escosura's (2009) assumption that real income per capita grew at a yearly rate of 0.8 per cent, the evolution of population (Vázquez-Presedo 1971) and the evolution of prices (Ferreres 2005).

Brazil: In the absence of reliable estimates of net revenues of the whole Brazilian railway network, I have taken the ratios between net revenues and GDP in 1913 provided by Summerhill (2003) and have driven them backward on the basis of: (i) the series of freight gross revenues of a sample of Brazilian railway lines estimated by Summerhill (2003), under the assumption that the operating ratio of the Brazilian railways was constant throughout the period under study and the lines of the sample represented a constant share of the total revenues of the network; ${ }^{9}$ (ii) the evolution of Brazilian nominal GDP. This has been taken, for 1900 onwards, from the Moxlad database, and, for the period before 1900 I have driven backwards the Moxlad estimates on the basis of Goldsmith (1986).

Mexico: First, I have estimated the amount of net revenues in 1910 on the basis of the gross revenues of the network, taken from Coatsworth (1981, pp. 42-43), and the operating ratio of the Ferrocarriles Nacionales, which accounted for two-thirds of the network in 1910, taken from Grunstein Dickter (1996, p. 202). Second, I have assumed the evolution of net revenues between 1873 and 1910 to be similar to that of the gross revenues of the network, available in Coatsworth (1981, pp. 42-43). This means that I assume, as in the case of Brazil, a constant operating ratio in the Mexican railway network. Nominal GDP data come, for 1900-1913, from Moxlad and for 1895-1899, from Estadísticas Históricas de México (http:// biblioteca.itam.mx/recursos/ehm.html). Before 1895, real yearly GDP figures have been obtained from Maddison (2001) through interpolation, and have been expressed in nominal terms, for 1885-95, on the basis of the evolution of an index of prices in Mexico City, taken from Estadísticas Históricas de México, and, for 1875-1885, on the basis of the index of export prices in Coatsworth (1981, p. 42). For 1873-1875 I have assumed that the growth rate of real and nominal GDP were the same.

Uruguay: For net railway revenues, see Herranz-Loncán (2011b). Nominal GDP is calculated on the basis of its level in 1955, taken from the official national accounts, and its previous evolution, as estimated by Bertino and Tajam (1999) and Bértola (1998).

${ }^{9}$ It is difficult to know how far these assumptions are from the real situation of Brazilian railways, and they, therefore, may have introduced some biases in the final figures of unknown magnitude. The sample of lines analysed by Summerhill (2003) accounted for a relatively constant share of the Brazilian railway mileage only since the mid 1870s (around 55 per cent). Before that date, however, they would represent $\sim 80$ per cent of the total mileage of the network; see Summerhill (2003, pp. 66-67). If this change is accounted for in the estimation, it hardly affects the final estimates (the Brazilian figure in Table 7 would be 0.79 instead of 0.81 ). This correction, however, has not been applied to the calculation, because the lines excluded from Summerhill's 
TABLE 6

THE CONTRIBUTION OF RAILWAYS TO ECONOMIC GROWTH IN LA4: THE CAPITAL TERM

\begin{tabular}{|l|c|c|c|}
\hline & (a) & (b) & (c) \\
\hline & $\begin{array}{c}\text { Railway km } \\
\text { per capita } \\
\text { yearly growth } \\
\text { rate (\%) }\end{array}$ & $\begin{array}{c}\text { Railway profit } \\
\text { share in national } \\
\text { income (net railway } \\
\text { revenues/GDP, \%) }\end{array}$ & $\begin{array}{c}\text { Railway contribution to } \\
\text { economic growth: capital } \\
\text { term (percentage points } \\
\text { of growth) (a } \times \text { b) }\end{array}$ \\
\hline Argentina (1865-1913) & 6.36 & 1.81 & 0.115 \\
\hline Brazil (1864-1913) & 6.25 & 0.81 & 0.051 \\
\hline Mexico (1873-1910) & 8.61 & 0.91 & 0.079 \\
\hline Uruguay (1874-1913) & 3.91 & 0.71 & 0.028 \\
\hline
\end{tabular}

Sources: see Tables 4 and 5.

railways, which introduces a certain bias of unknown direction in the final estimates, although the size of the bias might not be very large, given the apparent small size of the "supernormal» profits (or losses) in the railway sectors of these countries (see below).

As a result of these calculations, the capital term of the contribution of railways to growth in Brazil, Mexico and Uruguay would range yearly between 0.03 and 0.08 percentage points of growth, whereas the capital term of the growth contribution of the Argentinean railways would have been much higher (0.12). With the exception of Argentina, the reported percentages are in line with the equivalent Spanish figure in 1850-1912 (0.036) and the British estimate for 1830-1910 (ca. 0.07). In this context, the relative advantage of Argentina was mainly associated with the large size of the railway sector relative to GDP.

\subsection{The Contribution of Railways to Economic Growth: The TFP Term}

My estimation of the TFP term of the growth contribution of railways in the LA4 countries (including the TFP increase associated with the shift from the pre-railway transport system to railways) is based on the comparison between the cost of railway transport at the end of the period under study and the cost of traditional pre-railway transport. The necessary information on those costs can

\footnotetext{
(F'note continued)

sample and built after the mid 1870s may be assumed to have lower net revenues per $\mathrm{km}$ than the lines of the sample, which were among the most important of the Brazilian system.
} 
be taken from the available social saving estimates ${ }^{10}$. For Brazil and Mexico, the estimates come from Summerhill (2003) and Coatsworth (1981). In the case of Argentina, Summerhill (2000) carried out a preliminary calculation, which only measured the social savings of freight railway transport, and which has been recently revised and enlarged to include passenger transport (Herranz-Loncán 2011a). Finally, for Uruguay, I follow Herranz-Loncán (2011b), which provides complete (freight and passenger) social saving estimates for 1912-1913.

The estimation of the TFP term of the growth contribution of railways requires the transformation of the social savings into estimates of the direct real income gain due to the railways in each country, which can then be expressed as percentage points of growth per year (i.e. the last term of expression [2]). In order to do this, the social savings must be transformed into additional consumer surplus (i.e. corrected by the elasticity of demand), and increased by the amount of «supernormal» profits of the railway companies, as in Herranz-Loncán (2006). The resulting amount is then expressed in percentage points of yearly growth. This calculation is the objective of this subsection.

\subsubsection{Freight railway transport}

Starting with freight transport, Table 7 shows the railway social savings in the LA4 countries for the period 1910/1913. There are two main reasons for the differences between these countries' social saving estimates in row (i). The first is the different size of the railway sector in each economy (which has already been observed in the different ratios between net railway revenues and GDP in Table 5 above). This factor substantially increases the size of the social savings in Argentina (as it does with the capital term of the railway growth contribution). The second reason is the different ratio between railway fares and the average price of pre-railway transport means

10 As indicated previously (see footnote 4), ideally the social savings are based on a comparison between railway rates and the prices that alternative transport means would have had if the railway system had been closed in the year of reference of the calculation (e.g. 1913), rather than before the introduction of the railways. In contrast, in this research I am interested in a comparison between the railway rates in 1910-1913 and the prices of alternative transport means just before the advent of the railways (i.e. between 1864 and 1874, depending on the country). Therefore, by using cost data originally estimated for the end-point year, I am assuming that there were no productivity improvements in alternative transport means. If there were increases in productivity in those sectors, their unit cost figures in 1913 would be lower (and closer to the railway unit costs) than in the 1860s. Therefore, the use of figures for ca. 1913 would introduce a certain (downward) bias in my results, since these should ideally be based on (higher) mid-19 ${ }^{\text {th }}$ figures of pre-railway transport costs. This bias, however, can be assumed to be small, for two reasons. First, technological change and investment in road transport (the main alternative to the railways in all LA4 countries) was relatively small throughout the period under study. Second (and more importantly), due to the scarcity of information, social saving estimates are often based on alternative transport cost figures taken not only from the early $20^{\text {th }}$ century but also from the mid and late $19^{\text {th }}$ century. 
TABLE 7

SOCIAL SAVINGS OF FREIGHT RAILWAY TRANSPORT IN THE LA4 COUNTRIES IN 1910/1913

\begin{tabular}{|c|c|c|c|c|}
\hline & $\begin{array}{c}\text { Argentina } \\
\text { (1913) }\end{array}$ & $\begin{array}{c}\text { Brazil } \\
\mathbf{( 1 9 1 3 )}\end{array}$ & $\begin{array}{c}\text { Mexico }^{\mathbf{2}} \\
\mathbf{( 1 9 1 0 )}\end{array}$ & $\begin{array}{c}\text { Uruguay } \\
\mathbf{( 1 9 1 2 - 1 3 )}\end{array}$ \\
\hline $\begin{array}{c}\text { (a) Railway freight output } \\
\text { (million ton-km) }\end{array}$ & $8,985.4$ & $1,697.3$ & $3,456.1$ & 305.81 \\
\hline $\begin{array}{c}\text { (b) Railway rate in pesos/milreis } \\
\text { per ton-km (in pounds) }\end{array}$ & $\begin{array}{c}0.0101 \\
(0.0020)\end{array}$ & $\begin{array}{c}0.097 \\
(0.0023)\end{array}$ & $\begin{array}{c}0.023 \\
(0.0024)\end{array}$ & $\begin{array}{c}0.016 \\
(0.0033)\end{array}$ \\
\hline $\begin{array}{c}\text { (c) Railway freight output (million } \\
\text { pesos/milreis) (a } \times \text { b) }\end{array}$ & 90.64 & 165.32 & 79.53 & 4.74 \\
\hline $\begin{array}{c}\text { (d) Average alternative transport } \\
\text { rate in pesos/milreis per } \\
\text { ton-km (in pounds) }\end{array}$ & 0.067 & $1.388 / 0.727$ & 0.241 & 0.057 \\
\hline $\begin{array}{c}\text { (e) Alternative transport output } \\
\text { (million pesos/milreis) (a } \times \mathrm{d})\end{array}$ & $60.0130)$ & $(0.0323 / 0.0169)$ & $(0.0249)$ & $(0.0121)$ \\
\hline $\begin{array}{c}\text { (f) Railway rate/alternative trans- } \\
\text { port rate (\%) (b/e) }\end{array}$ & 6.67 & $7.01 / 13.39$ & 9.54 & 3.66 \\
\hline $\begin{array}{c}\text { (g) Social savings (million pesos/ } \\
\text { milreis) (e-c) }\end{array}$ & 513.50 & $2,191.39 /$ & 754.08 & 12.61 \\
\hline (i) As a percentage of GDP & 20.6 & $38.45 / 18.75$ & 24.33 & 3.83 \\
\hline
\end{tabular}

Notes: ${ }^{1}$ For Argentina, all monetary amounts are in gold pesos.

${ }^{2}$ For Mexico, Coatsworth's data have been expressed in Mexican pesos of 1910.

Sources: For Mexico and Brazil, own elaboration from Coatsworth (1981) and Summerhill (2003). For Argentina, Herranz-Loncán (2011a) and for Uruguay, Herranz-Loncán (2011b).

in each country (row $\mathrm{f}$ of Table 7). This ratio depends mainly on the assumption made in each case on the railway transport share that would have had to be transported by carts or pack animals in the absence of railways, since these were the most expensive alternative transport means. Unit transport costs were, by contrast, much lower in water freight transport.

In the case of Argentina, for instance, Herranz-Loncán (2011a) suggests a unit cost for road transport of 0.070 gold pesos per ton-km; much higher than both the railway average rate in 1913 (0.010) and water transport rates using the River Paraná (0.008). In the case of Uruguay, the road transport rate is estimated as 0.056 pesos per ton- $\mathrm{km}$, and the railway and water transport rates as 0.016 and 0.006 pesos per ton-km, respectively (HerranzLoncán, 2011b). The cheapest of the three transport means was river or coastal navigation. In fact, the replacement of water transport by railways did not mean any direct saving of resources, and the use of the railways was 
only justified by the presence of hidden costs in water transport (which are not included here and are not usually considered in the social saving estimations due to the measurement difficulties involved) ${ }^{11}$.

Regarding the importance of each pre-railway means of transport, in the cases of Mexico and Brazil I have accepted Coatsworth's and Summerhill's assumption that, in the absence of railways, all railway freight transport would have been carried by road. The lack of waterways or coastal navigation routes parallel to the railway lines in these countries makes this assumption plausible. By contrast, the situation was completely different in Argentina and Uruguay, where a significant share of railway transport followed the direction of the coastline or navigable rivers. The social saving estimations for these countries are based on the assumption that, in the absence of railways, 13.1 per cent of Argentinean railway freight transport and 21 per cent in the case of Uruguay would have been moved by river. These percentages are the outcome of an approximate estimation of the share of railway freight traffic that ran parallel or close to navigable rivers in these two countries ${ }^{12}$.

To sum up, the percentage of freight railway traffic that would have been moved by overland transport in the absence of the railways would be 86.9 per cent in Argentina and 79 per cent in Uruguay, compared with 100 per cent in Mexico and Brazil ${ }^{13}$. Together with the size of the railway sector in each country, these percentages explain the differences between the LA4 social saving estimates, which were very high, in terms of GDP, in Argentina, Brazil and Mexico, but very low in Uruguay ${ }^{14}$.

11 See Coatsworth (1981, pp. 104-105) and Summerhill (2003, p. 61).

12 In the case of Argentina, this percentage is the sum of: (i) the share of the Buenos AiresRosario company (whose main line ran parallel to the Paraná river) over total freight railway transport in 1907 (the last year for which this information is available, just before the merger of this company with the Ferrocarril Central Argentino), and (ii) the freight transported by the companies of the Mesopotamia (the Provincia de Santa Fe, Nordeste and Entre Ríos companies), which ran to a large extent in the same directions as the Paraná and Uruguay rivers. This information has been obtained from Dirección General de Ferrocarriles, Estadística de los ferrocarriles en explotación (1907/1913). As for the Uruguayan percentage, it is an approach to the share of railway traffic stemming from areas close to the Uruguay River or the La Plata estuary; see Herranz-Loncán (2011b).

${ }^{13}$ In the case of Argentina and Uruguay, in the absence of railways, livestock would have been moved by droving. Livestock accounted for 10.05 per cent of total railway freight transport in Argentina and 18.78 per cent in Uruguay. This would not affect the results of the analysis since, although the prices of droving services were much lower per ton-km than carting rates, droving involved a high indirect cost associated with livestock's weight loss during the journey. On this subject, see Herranz-Loncán (2011b).

14 Differences between countries in railway rates or in prices of alternative transport means also introduce differences in the social saving estimates. For instance, railway rates were very high in Uruguay, and road transport prices seem to have been lower in Argentina and, especially, in Uruguay, than in the rest of LA4. Nevertheless, it is difficult to draw definite conclusions from these differences, due to the large error margin involved in the figures. As O'Brien (1983, p. 177) warned, this is one of the main drawbacks of social saving calculations. 
TABLE 8

ADDITIONAL CONSUMER SURPLUS OF RAILWAY FREIGHT TRANSPORT IN LA4 IN 1910/1913

\begin{tabular}{|l|c|c|c|c|}
\hline & $\begin{array}{c}\text { Argentina } \\
\mathbf{( 1 9 1 3 )}\end{array}$ & $\begin{array}{c}\text { Brazil } \\
\mathbf{( 1 9 1 3 )}\end{array}$ & $\begin{array}{c}\text { Mexico } \\
\mathbf{( 1 9 1 0 )}\end{array}$ & $\begin{array}{c}\text { Uruguay } \\
\mathbf{( 1 9 1 2 - 1 9 1 3 )}\end{array}$ \\
\hline $\begin{array}{c}\text { Social saving of railway freight trans- } \\
\text { port (million pesos/milreis) }\end{array}$ & 513.50 & $\begin{array}{c}1,068.32 / \\
2,191.34\end{array}$ & 754.08 & 12.61 \\
\hline Price elasticity of demand & -0.49 & -0.6 & -0.5 & -0.77 \\
\hline $\begin{array}{c}\text { Additional consumer surplus of railway } \\
\text { freight transport (million pesos/milreis) }\end{array}$ & 289.89 & $\begin{array}{c}510.31 / \\
783.05\end{array}$ & 355.91 & 7.18 \\
\hline As a \% of GDP & 11.61 & $\begin{array}{c}8.97 / \\
13.77\end{array}$ & 11.48 & 2.19 \\
\hline
\end{tabular}

Sources: For Argentina, Mexico and Brazil, own calculation on the basis of Coatsworth (1981), Summerhill (2000) and (2003) and Table 7; for Uruguay, Herranz-Loncán (2011b).

The next step in the estimation of the TFP term of the growth contribution of railways is the correction of the freight social saving figures for the price elasticity of demand in each country, in order to obtain unbiased estimates of the additional consumer surplus of railway freight transport. This elasticity has been estimated as -0.5 in Mexico (Coatsworth 1981), as -0.6 in Brazil and -0.49 in Argentina (Summerhill 2000 and 2003) and as -0.77 in Uruguay (Herranz-Loncán 2011b). The estimates of additional consumer surplus of railway freight transport that result from applying these elasticities to the social saving figures are shown in Table $8^{15}$.

\subsubsection{Passenger transport}

These figures must be increased by the additional consumer surplus of railway passenger transport. In the case of passengers, the additional consumer surplus should take into account not only the savings of transport costs but also the time saved by individuals thanks to the replacement of (slower) traditional transport means by railways. This requires estimating the share of travelling time that would have to be deducted from the travellers' working time in an economy without railways, as well as the railway passengers' average hourly wage.

15 The ratio between the social savings and the additional consumer surplus is given by $\left[\left(\varphi^{1+\varepsilon}-1\right) /(1+\varepsilon)(\varphi-1)\right]$, where $\varepsilon$ is the elasticity of transport demand and $\varphi$ is the ratio between counterfactual and railway transport prices; see Fogel (1979, pp. 10-11). Assuming the same level of demand elasticity for the four countries $(0.6$, which is the average of the four estimated elasticity figures) does not change the conclusions of this research. 
As in the case of freight, Coatsworth (1981) and Summerhill (2003) produced careful estimates of the social savings of railway passenger transport for Mexico and Brazil, respectively. These were based on the assumption that, in the absence of the railways, first-class passengers would have used stagecoach transport, but second-class passengers would have walked instead. Here I have followed a similar approach. In addition, in order to transform the social saving estimates into additional consumer surplus figures, in the case of first-class transport I have assumed a demand elasticity of $\sim-1$, which is reasonable for a high-price passenger transport means with some luxury character ${ }^{16}$. By contrast, in the case of the second class, I assume that all passengers would have travelled in the absence of railroads, that is, that their journeys were mainly made out of necessity ${ }^{17}$. The result of this strategy is an estimate of the additional consumer surplus of passenger railway transport in Brazil and Mexico, which is largely based on the information provided by those authors. For Argentina and Uruguay, I perform a similar estimation, although, as in the case of freight, I assume that, in the absence of the railways, a certain number of Argentinean and Uruguayan first-class passengers would have used river navigation to move. I estimate this percentage as 16.8 in Argentina and 16.6 in Uruguay ${ }^{18}$.

As for the savings in travel time, following Summerhill (2005), I value the travel time of second-class travellers as a weighted average of the hourly wage of industrial and agricultural workers (taking as weights the shares of industry and agriculture within the active population), and that of first-class travellers at twice that amount. Finally, I also consider, as in the cases of Mexico and Brazil, that only about half of the time savings were savings in working time and must therefore be included in the estimation of the additional consumer surplus. The results of the estimation are shown in Table 9.

Table 10 shows the estimates of additional consumer surplus of railway passenger transport that result from correcting the estimates for first-class passengers for the elasticity of demand. The figures reported in the table are much lower than in the case of freight; this is consistent with the low importance of passenger transport, according to Coatsworth (1981) and

16 See, for instance, Boyd and Walton (1972, pp. 247-250) and Metzer (1977, p. 73).

17 This would be equivalent to assuming a null elasticity to the increasing cost of travelling. This assumption might not be completely appropriate for a certain share of second-class travel or for certain countries. For instance, in the case of Uruguay, Herranz-Loncán (2011b, p. 15) highlights the low difference between first- and second-class passenger railway rates and, arguably, between first- and second-class travellers and motivations. Assuming a demand elasticity of -1 in the case of the second class, however, does not significantly change the estimates of additional consumer surplus of passenger transport. The maximum difference is found in the cases of Argentina and Brazil where the estimates would be reduced from 1.85 and 1.96 to 1.30 and 1.44 per cent of GDP, respectively. In Mexico and Uruguay, the change would be virtually zero. In all cases, the effect on the TFP term of the growth contribution of railways would be negligible.

18 Those percentages are calculated on the basis of the same assumptions as in the case of freight. 
TABLE 9

SOCIAL SAVINGS OF RAILWAY PASSENGER TRANSPORT IN LA4 IN 1910/13

\begin{tabular}{|c|c|c|c|c|}
\hline & $\begin{array}{l}\text { Argentina } \\
\text { (1913) }\end{array}$ & $\begin{array}{l}\text { Brazil } \\
(1913)\end{array}$ & $\begin{array}{l}\text { Mexico } \\
(1910)\end{array}$ & $\begin{array}{c}\text { Uruguay } \\
(1912-1913)\end{array}$ \\
\hline \multicolumn{5}{|l|}{ (A) First-class passenger transport } \\
\hline (a) Railway output (million passenger-km) & $1,309.43$ & 605.19 & 229.91 & 68.155 \\
\hline (b) Railway rate in pesos/milreis per passenger-km (in pounds) & $\begin{array}{c}0.015 \\
(0.0031)\end{array}$ & $\begin{array}{c}0.047 \\
(0.0011)\end{array}$ & $0.037(0.0038)$ & $\begin{array}{c}0.019 \\
(0,0041)\end{array}$ \\
\hline (c) Railway output (million pesos/milreis) $(\mathrm{a} \times \mathrm{b})$ & 20.21 & 28.44 & 8.45 & 1.30 \\
\hline $\begin{array}{l}\text { (d) Unit value of working travel time in pesos/milreis per hour } \\
\text { (in pounds) }\end{array}$ & $\begin{array}{c}0.402 \\
(0.0798)\end{array}$ & $\begin{array}{c}0.904 \\
(0.0210)\end{array}$ & $0.214(0.0221)$ & $\begin{array}{c}0.274 \\
(0.0582)\end{array}$ \\
\hline (e) Railway passenger transport average speed (km per hour) & 39.4 & 39 & 40 & 34.4 \\
\hline $\begin{array}{l}\text { (f) Working travel time by railway (million hours) (50\% of (a) at (e) km } \\
\text { per hour) }\end{array}$ & 16.617 & 7.759 & 2.874 & 0.991 \\
\hline $\begin{array}{l}\text { (g) Value of the working travel time by railway (million pesos/milreis) } \\
(\mathrm{d} \times \mathrm{f})\end{array}$ & 6.680 & 7.014 & 0.615 & 0.271 \\
\hline (h) Counterfactual water transport output (million passenger-km) & 219.52 & - & - & 11.29 \\
\hline $\begin{array}{l}\text { (i) Counterfactual water transport rate in pesos/milreis per passenger-km } \\
\text { (in pounds) }\end{array}$ & $\begin{array}{c}0.0057 \\
(0.0011)\end{array}$ & - & - & $\begin{array}{c}0.0048 \\
(0.0010)\end{array}$ \\
\hline $\begin{array}{l}\text { (j) Counterfactual water transport output (million pesos/milreis) } \\
(\mathrm{h} \times \mathrm{i})\end{array}$ & 1.251 & - & - & 0.054 \\
\hline (k) Water passenger transport average speed (km per hour) & 12 & - & - & 12 \\
\hline $\begin{array}{l}\text { (l) Working travel time by water transport (million hours) (50 per cent of } \\
\text { (h) at km per hour) }\end{array}$ & 9.147 & - & - & 0.0023 \\
\hline $\begin{array}{l}\text { (m) Value of the working travel time by water transport (million pesos/ } \\
\text { milreis) }(\mathrm{d} \times \mathrm{l})\end{array}$ & 3.677 & - & - & 0.00062 \\
\hline
\end{tabular}




\begin{tabular}{|c|c|c|c|c|}
\hline & $\begin{array}{l}\text { Argentina } \\
\text { (1913) }\end{array}$ & $\begin{array}{l}\text { Brazil } \\
(1913)\end{array}$ & $\begin{array}{c}\text { Mexico } \\
(1910)\end{array}$ & $\begin{array}{c}\text { Uruguay } \\
(1912-1913)\end{array}$ \\
\hline (n) Counterfactual road transport output (million passenger-km) & $1,089.91$ & 605.19 & 229.91 & 56.87 \\
\hline $\begin{array}{l}\text { (o) Counterfactual road transport rate in pesos/milreis per passenger-km) } \\
\text { (in pounds) }\end{array}$ & $\begin{array}{l}0.0246 \\
(0.0049)\end{array}$ & $\begin{array}{c}0.360 \\
(0.0084)\end{array}$ & $\begin{array}{c}0.120 \\
(0.0123)\end{array}$ & $\begin{array}{c}0.0614 \\
(0.0131)\end{array}$ \\
\hline (p) Counterfactual road transport output (million pesos/milreis) $(\mathrm{n} \times \mathrm{o})$ & 22.812 & 217.87 & 27.609 & 3.494 \\
\hline (q) Road passenger transport average speed (km per hour) & 17.25 & 13 & 15 & 6.5 \\
\hline $\begin{array}{l}\text { (r) Working travel time by road transport (million hours) (50\% of (n) at (q) } \\
\text { km per hour) }\end{array}$ & 31.592 & 23.277 & 7.664 & 4.374 \\
\hline $\begin{array}{l}\text { (s) Value of the working travel time by road transport (million } \\
\text { pesos/milreis) }(\mathrm{d} \times \mathrm{r})\end{array}$ & 12.700 & 21.042 & 1.640 & 1.199 \\
\hline (t) Savings on transport costs (million pesos/milreis) $(\mathrm{j}+\mathrm{p}-\mathrm{c})$ & 7.855 & 189.43 & 19.156 & 2.248 \\
\hline (u) Savings on travel time (million pesos/milreis) $(\mathrm{m}+\mathrm{s}-\mathrm{g})$ & 9.697 & 14.028 & 1.025 & 0.928 \\
\hline (v) Total savings (million pesos/milreis) $(\mathrm{t}+\mathrm{u})$ & 17.552 & 203.45 & 20.181 & 3.176 \\
\hline (w) As a percentage of GDP & 0.70 & 3.58 & 0.65 & 2.27 \\
\hline \multicolumn{5}{|l|}{ (B) Second-class passenger transport } \\
\hline (a) Railway output (million passenger-km) & $1,544.28$ & $1,012.00$ & 830.54 & 47.231 \\
\hline (b) Railway rate in pesos/milreis per passenger-km (in pounds) & $\begin{array}{c}0.010 \\
(0.0020)\end{array}$ & $\begin{array}{c}0.027 \\
(0.0006)\end{array}$ & $\begin{array}{c}0.014 \\
(0.0015)\end{array}$ & $\begin{array}{c}0.016 \\
(0.0033)\end{array}$ \\
\hline (c) Railway output (million pesos/milreis) $(\mathrm{a} \times \mathrm{b})$ & 15.191 & 26.818 & 11.895 & 0.734 \\
\hline (d) Unit value of working travel time in pesos/milreis per hour (in pounds) & $\begin{array}{c}0.201 \\
(0.0399)\end{array}$ & $\begin{array}{c}0.452 \\
(0.0105)\end{array}$ & $\begin{array}{c}0.107 \\
(0.0110)\end{array}$ & $\begin{array}{c}0.137 \\
(0.0291)\end{array}$ \\
\hline
\end{tabular}


TABLE 9 (Cont.)

\begin{tabular}{|c|c|c|c|c|}
\hline (e) Railway passenger transport average speed (km per hour) & 39.4 & 39 & 40 & 34.4 \\
\hline $\begin{array}{l}\text { (f) Working travel time by railway (million hours) (50\% of (a) at (e) km } \\
\text { per hour) }\end{array}$ & 19.598 & 12.974 & 10.382 & 0.687 \\
\hline $\begin{array}{l}\text { (g) Value of the working travel time by railway (million pesos/milreis) } \\
(\mathrm{d} \times \mathrm{f})\end{array}$ & 3.939 & 5.864 & 1.111 & 0.094 \\
\hline (h) Counterfactual passenger transport average speed ( $\mathrm{km}$ per hour) & 3 & 3 & 3 & 3 \\
\hline $\begin{array}{l}\text { (i) Counterfactual working travel time (million hours) (50\% of (a) at (h) } \\
\mathrm{km} \text { per hour) }\end{array}$ & 257.381 & 168.667 & 138.423 & 7.872 \\
\hline $\begin{array}{l}\text { (j) Counterfactual value of the working travel time (million pesos/ } \\
\text { milreis) }(\mathrm{d} \times \mathrm{i})\end{array}$ & 51.733 & 76.237 & 14.811 & 1.078 \\
\hline (k) Savings on transport costs (million pesos/milreis) $(-\mathrm{c})$ & -15.191 & -26.818 & -11.895 & -0.734 \\
\hline (l) Savings on travel time (million pesos/milreis) $(\mathrm{j}-\mathrm{g})$ & 47.794 & 70.373 & 13.700 & 0.984 \\
\hline (v) Total savings (million pesos/milreis) $(\mathrm{t}+\mathrm{u})$ & 32.603 & 43.555 & 1.805 & 0.251 \\
\hline (w) As a percentage of GDP & 1.31 & 0.77 & 0.06 & 0.18 \\
\hline
\end{tabular}

Sources and notes: For Argentina, Herranz-Loncán (2011a), except for wages, from Cortés Conde (1975), and composition of the active population, from the 1914 National Census.

For Mexico, Coatsworth (1981) and information on minimum wages and active population by sector in 1910 from Estadísticas Históricas de México (http://biblioteca.itam.mx/recursos/ehm.html); I have taken the average wage of railway workers provided by Coatsworth (1981) as representative of the average wages of the higher paid sectors (manufacturing and mining) and have assumed that the ratio between the minimum and the average wages of each sector was the same.

For Brazil, Summerhill (2003) and (2005)

For Uruguay, Herranz-Loncán (2011b), except for the composition of the active population, which has been taken from the 1908 Uruguayan Statistical Yearbook, and wage data for 1913, which have been kindly provided by Luis Bértola. 
TABLE 10

ADDITIONAL CONSUMER SURPLUS OF RAILWAY PASSENGER TRANSPORT IN LA4 (CORRECTED BY THE ELASTICITY OF DEMAND)

\begin{tabular}{|l|c|c|c|c|}
\hline & $\begin{array}{c}\text { Argentina } \\
\mathbf{( 1 9 1 3 )}\end{array}$ & $\begin{array}{c}\text { Brazil } \\
\mathbf{( 1 9 1 3 )}\end{array}$ & $\begin{array}{c}\text { Mexico } \\
\mathbf{( 1 9 1 0 )}\end{array}$ & $\begin{array}{c}\text { Uruguay } \\
\mathbf{( 1 9 1 2 - 1 9 1 3 )}\end{array}$ \\
\hline $\begin{array}{c}\text { (a) First-class (million pesos/ } \\
\text { milreis) }\end{array}$ & 13.51 & 67.64 & 10.62 & 1.74 \\
\hline $\begin{array}{c}\text { (b) Second-class (million pesos/ } \\
\text { milreis) }\end{array}$ & 32.60 & 43.55 & 1.81 & 0.25 \\
\hline Total (a + b) & 46.11 & 111.19 & 12.43 & 1.99 \\
\hline As a \% of GDP & 1.85 & 1.96 & 0.40 & 0.98 \\
\hline
\end{tabular}

Sources: see text and Table 10.

Summerhill (2003), in the direct benefits that Mexico and Brazil received from railways. The only exception to this rule is Uruguay, due to the low size of the social saving of freight transport in this country.

The scarcity of adequate information prevents us from including in the additional consumer surplus estimates other sorts of freight transport (essentially high-speed freight), which accounted for a non-negligible share of railway revenues ${ }^{19}$. This absence introduces a certain downward bias in the additional consumer surplus figures. This bias, however, is probably small. Since most of that traffic should be considered as a completely new good, its contribution to the additional consumer surplus may be expected to be rather low ${ }^{20}$.

\subsubsection{Supernormal profits}

Finally, in order to obtain a complete measure of the real income gain provided by railways in each country, the estimates of the additional consumer surplus of freight and passenger transport should be corrected for the potential presence of supernormal profits in the railway system. Supernormal profits should be calculated as the difference between gross revenues and total expenditure, including capital costs. The latter, in turn, may be calculated as a percentage of the value of the stock of railway capital, which should include both the amortisation rates and the opportunity cost of capital.

19 For instance, this kind of traffic accounted for 11.8 per cent of the total revenues of the Brazilian railway companies in 1913 (percentage estimated from Summerhill, 2003), for 4.8 per cent in the case of Argentina (estimated from Dirección General de Ferrocarriles, Estadistica de los ferrocarriles en explotación, 1913), and for 4.9 in Uruguay (see Herranz-Loncán 2011b).

${ }^{20}$ On this issue see, for instance, Hausman (1994). 
This calculation, however, is not easy, due to the accounting procedures used at the time. On the one hand, operating costs often included some replacement and new investment expenditures, which were not, therefore, incorporated to the capital account. On the other hand, railway capital was rarely depreciated, leading to an overstatement of the capital stock figures ${ }^{21}$. In addition, in those countries, such as Argentina or Brazil, where railway subsidies mainly consisted of guaranteed returns upon investment, capital figures were often artificially inflated by the companies. In this context, it is very difficult to obtain an accurate estimate of supernormal profits. Therefore, here I simply compare the difference between the net returns of each system and the opportunity cost of capital, approached through yields to sovereign bonds, in order to obtain a preliminary idea of their potential size.

By 1912-1913, railway net operating returns were around 4 per cent of total accumulated investment in Argentina, 3.6 per cent in Brazil and 4 per cent in Uruguay $^{22}$. Given that yields on sovereign bonds were 4.88 per cent in Argentina and 4.97 per cent in Brazil at the time (Flandreau and Zumer 2004), supernormal profits seem to have been negative in those railway systems, since net revenues would not have been sufficient to cover capital costs. However, those negative returns would be relatively small, especially compared with the additional consumer surplus of railway transport. For instance, in the case of Argentina and Brazil, if the yields on bonds are taken as a proxy of the opportunity cost of capital and amortisation needs are ignored, this correction would amount to just 3-4.5 per cent of the additional consumer surplus. Therefore, given the uncertainty of the real value of investment in these railway systems and the low relative importance of negative returns, I have decided to exclude this correction from the final figures.

Table 11 summarises the results of the estimation of the direct real income gain of railway transport in each country. These figures make it possible to calculate the TFP term of the growth contribution of railways by expressing the income gain as a contribution to the yearly growth rate of the economy between the start of the railway era and the reference year of the estimation (row f). The figures in the table clearly show that, from the viewpoint of the TFP component of the railway growth share, the LA4

21 See, e.g. Summerhill (2003, p. 169).

22 Railway net returns come, in the case of Argentina, from Dirección General de Ferrocarriles, Estadistica de los ferrocarriles en explotación (1913); in the case of Brazil, from Summerhill (2003); and, in the case of Uruguay, from Herranz-Loncán (2011b). In the case of Mexico, there are no available estimates of the total capital invested in the railway network and, therefore, it is not possible to calculate an average rate of return; see Ortiz Hernán (1996, p. 28). However, if the net revenues of the system in 1910 are combined with the estimate of 1,130 million pesos of foreign investment (which accounted for most of the network) in Connolly (1997, p. 83), the resulting percentage is less than 3 per cent. Therefore, the situation would not be very different from the other three countries. 
TABLE 11

DIRECT REAL INCOME GAIN FROM RAILWAY TRANSPORT IN LA4, 1910/1913

\begin{tabular}{|l|c|c|c|c|}
\hline & $\begin{array}{c}\text { Argen- } \\
\text { tina } \\
(\mathbf{1 9 1 3})\end{array}$ & $\begin{array}{c}\text { Brazil } \\
\mathbf{( 1 9 1 3 )}\end{array}$ & $\begin{array}{c}\text { Mexico } \\
\mathbf{( 1 9 1 0})\end{array}$ & $\begin{array}{c}\text { Uruguay } \\
(\mathbf{1 9 1 2 - 1 9 1 3})\end{array}$ \\
\hline $\begin{array}{c}\text { (a) Freight transport additional consumer } \\
\text { surplus (million pesos/milreis) }\end{array}$ & 289.89 & $\begin{array}{c}510.31 / \\
783.05\end{array}$ & 355.91 & 7.18 \\
\hline $\begin{array}{c}\text { (b) Passenger transport additional consumer } \\
\text { surplus (million pesos/milreis) }\end{array}$ & 46.11 & 111.19 & 12.43 & 1.99 \\
\hline (c) Total (a + b) & 336.00 & $\begin{array}{c}621.50 / \\
894.24\end{array}$ & 368.34 & 9.17 \\
\hline $\begin{array}{c}\text { (d) As a \% of GDP of the year of reference } \\
\text { (e) As a \% of the income per capita increase } \\
\text { since the beginning of the railway era }\end{array}$ & 13.46 & $\begin{array}{c}10.93 / \\
15.72\end{array}$ & 11.88 & 2.78 \\
\hline $\begin{array}{c}\text { (f) TFP term of the railway growth contri- } \\
\text { bution (percentage points per year) }\end{array}$ & 0.533 & $\begin{array}{c}51.44 / \\
74.01\end{array}$ & $20.257 /$ \\
0.369 & 0.448 & 0.086 \\
\hline
\end{tabular}

Sources: see text.

countries may be divided into two groups. On the one hand, in Argentina, Brazil and Mexico the TFP term accounted for 0.26 to 0.53 percentage points of growth during the railway era, that is, a much higher amount than in Britain or Spain. By contrast, in Uruguay, that share was only around 0.09 percentage points, and rather close therefore to the equivalent British or Spanish figures.

\subsection{Summary}

The figures presented in the previous subsections allow a preliminary estimation of the growth contribution of railways in the LA4 countries before World War I, which is presented in Table $12^{23}$. The figures in the table clearly confirm the exceptional character of Uruguay within the LA4 sample. Despite the substantial effort made to endow the Uruguayan economy with one of the densest networks of the continent, the growth contribution of Uruguayan railways was much lower than in the rest of LA4, and was also lower than in Britain and Spain, both in absolute and relative terms. By contrast, the

${ }^{23}$ As is usual in this kind of exercise (see above), the figures in Table 12 exclude the indirect effects of railways, due to the difficulties involved in quantifying them. These might have been especially relevant in those cases, such as Argentina, in which the railways allowed the exploitation of the natural resources of a large share of the territory which would have remained idle without them (Cortés Conde 1979; Lewis 1983, pp. 219-220). 
TABLE 12

THE CONTRIBUTION OF RAILWAYS TO PRODUCTIVITY GROWTH IN LA4 BEFORE 1914 (PERCENTAGE POINTS PER YEAR)

\begin{tabular}{|l|c|c|c|c|}
\hline & $\begin{array}{c}\text { Argentina } \\
\mathbf{( 1 8 6 5 - 1 9 1 3 )}\end{array}$ & $\begin{array}{c}\text { Brazil } \\
\mathbf{( 1 8 6 4 - 1 9 1 3 )}\end{array}$ & $\begin{array}{c}\text { Mexico } \\
(\mathbf{1 8 7 3 - 1 9 1 0})\end{array}$ & $\begin{array}{c}\text { Uruguay } \\
\mathbf{( 1 8 7 4 - 1 9 1 3 )}\end{array}$ \\
\hline $\begin{array}{c}\text { (a) Railway capital stock per } \\
\text { capita growth }\end{array}$ & 6.36 & 6.25 & 8.61 & 3.91 \\
\hline $\begin{array}{c}\text { (b) Railway profits share in } \\
\text { national income }\end{array}$ & 1.81 & 0.81 & 0.91 & 0.71 \\
\hline $\begin{array}{c}\text { (c) Railway capital contribution } \\
\text { (a } \times \text { b) }\end{array}$ & 0.115 & 0.051 & 0.079 & 0.028 \\
\hline (d) TFP contribution & 0.533 & $0.257 / 0.369$ & 0.448 & 0.086 \\
\hline $\begin{array}{c}\text { (e) Total railway contribution } \\
\text { (c + d) }\end{array}$ & 0.648 & $0.308 / 0.420$ & 0.527 & 0.114 \\
\hline (f) GDP per capita growth & 3.00 & 0.50 & 2.17 & 1.35 \\
\hline $\begin{array}{c}\text { (g) Railway contribution as } \% \\
\text { of GDP growth (e/f) }\end{array}$ & 21.60 & $61.60 / 84.18$ & 24.29 & 8.44 \\
\hline
\end{tabular}

Sources: GDP per capita growth rates are calculated, in the case of Argentina, from estimates by Della Paolera et al. (2003) (I assume a $0.8 \%$ yearly growth rate before 1875, following Prados de la Escosura 2009); in the case of Brazil, from Maddison (2001); for 1865-1870 I have driven backwards Maddison's estimates on the basis of Goldsmith (1986); in the case of Mexico, from Maddison's database; and, in the case of Uruguay, from Bértola (1998). For other magnitudes, see text.

growth contribution of railways in Argentina, Brazil and Mexico is, from all angles, impressive. In absolute terms, railways provided between 0.3 and 0.7 percentage points of growth per year in each of these three countries, that is, between two and four times the equivalent figure in Britain or Spain.

The difference between Uruguay and the other countries of the sample is partially associated with the low level of the capital term, due to the slowdown of Uruguayan railway construction after the 1890s. However, the main reasons for this outcome are, on the one hand, the relatively low advantage of railways over the alternative transport means in Uruguay and, on the other hand, the small size of Uruguayan railway output in 1913. Whereas the former is associated with the possibility of using water transport, the underdevelopment of the Uruguayan railway sector would be the result of several factors. As indicated in Herranz-Loncán (2011b), the specialisation of the country in livestock production did not generate much transport output per $\mathrm{km}^{2}$; in addition, the small size of the country and the absence of frontier territory increased the share of short distance journeys over total transport, reducing therefore the competitiveness of the railways over traditional overland transport means; and, finally, the availability of alternative water 
TABLE 13

THE CONTRIBUTION OF RAILWAYS TO PRODUCTIVITY GROWTH IN ARGENTINA, BRAZIL AND MEXICO BEFORE 1914 (PERCENTAGE POINTS PER YEAR): A COUNTERFACTUAL ANALYSIS

\begin{tabular}{|l|c|c|c|}
\hline & $\begin{array}{c}\text { Argentina } \\
\mathbf{( 1 8 6 5 - 1 9 1 3 )}\end{array}$ & $\begin{array}{c}\text { Brazil } \\
(\mathbf{1 8 6 4 - 1 9 1 3 )}\end{array}$ & $\begin{array}{c}\text { Mexico } \\
(\mathbf{1 8 7 3 - 1 9 1 0 )}\end{array}$ \\
\hline $\begin{array}{c}\text { (a) Actual growth contribution of the railways } \\
\text { (percentage points of growth per year) }\end{array}$ & 0.648 & $0.308 / 0.420$ & 0.527 \\
\hline $\begin{array}{c}\text { (b) Counterfactual I: same growth rate of the } \\
\text { railway capital stock p.c. as in Uruguay }\end{array}$ & 0.604 & $0.288 / 0.401$ & 0.483 \\
\hline $\begin{array}{c}\text { (c) Counterfactual II: same size of the railway } \\
\text { sector (relative to GDP) as in Uruguay }\end{array}$ & 0.257 & $0.179 / 0.235$ & 0.323 \\
\hline $\begin{array}{c}\text { (d) Counterfactual III: same ratio between } \\
\text { alternative and railway transport cost as in } \\
\text { Uruguay }\end{array}$ & 0.473 & 0.200 & 0.271 \\
\hline
\end{tabular}

transport reduced the use of the railway system. In other words, and unlike the situation in the other LA4 countries, the geography of Uruguay did not provide an adequate context for achieving all the potential benefits of the new technology.

Table 13 provides a first approach to the relative importance of such factors in explaining the high growth contribution of railways in Argentina, Brazil and Mexico compared with Uruguay. The table indicates the level that the railway growth contribution (in percentage points of growth) would have reached in each of these three countries in three counterfactual situations: (i) if the railway capital stock per capita had grown at the same rate as in Uruguay; (ii) if the railway sector had had the same size (relative to GDP) as in Uruguay ${ }^{24}$; and (iii) if the ratio between alternative and railway transport costs had been the same as in Uruguay.

Although these counterfactual estimates must be treated with caution, since they are conditional on the coeteris paribus assumption, they confirm that the advantage of Argentina, Brazil and Mexico over Uruguay was mainly associated with the relative size of the railway transport sector and the difference between railway rates and pre-railway transport costs. By contrast, the rate of growth of the railway capital stock per capita was only of minor importance. More specifically, in the case of Argentina the comparatively high growth contribution of the railways would mainly be explained by the large share that railways accounted for in the economy. Whereas, in the cases of Brazil and Mexico, the huge cost advantage of railways over the

${ }^{24}$ This would affect both the capital term of the growth contribution (through the railway profits share in national income) and the TFP term (through larger social saving estimates). 
alternative transport means (largely associated with the predominance of overland transport in the pre-railway economy) had similar or higher explanatory power than the size of the railway sector.

The last row of Table 12 reports the growth contribution of railways as a percentage of the actual rate of growth of income per capita in each country. In this regard, the low level of the growth contribution of Uruguay's railways, just 8.7 per cent of the growth of income per capita (i.e. a much lower percentage than in Britain or Spain), also stands out. By contrast, in Argentina and Mexico railways accounted for 20 to 25 per cent of the growth of income per capita between the start of the railway era and 1910/1913. These percentages are quite impressive for a single sector and significantly higher than the equivalent Spanish or British figures.

Finally, in the case of Brazil, although the contribution of railways was lower than in Argentina and Mexico in terms of percentage points of growth, it represented a much higher share, between 62 and 84 per cent, of the total growth of the Brazilian economy during the decades prior to 1914 . This mainly reflects the fact that Brazil was a stagnated economy during the period under study. However, this stagnation was hiding huge regional imbalances and considerable changes in the economic geography of the country. Whereas some regions, especially in the south-east, were growing at very high rates and increasing their importance within the whole economy, other areas, mainly in the north, were sinking in a catastrophic crisis. The fact that the growth of the most dynamic regions is not clearly reflected in the aggregate GDP growth estimates is an indication of the disastrous character that the first globalisation had for some areas of Brazil. As might be expected, the densest Brazilian railway sub-networks were established in the fastest-growing areas of the country (around Sao Paulo and Rio de Janeiro), being indeed responsible for a substantial share of their economic growth.

As has been indicated, the growth contribution of railways in Argentina, Brazil and Mexico was much higher than the equivalent Spanish or British figure. In absolute terms (in percentage points of yearly growth) it was significantly higher, on average, than the whole contribution of steam technology to British economic growth during the $19^{\text {th }}$ and early $20^{\text {th }}$ century (Crafts 2004b). The railways of these three Latin American countries provide, therefore, an interesting example of a technology whose contribution to economic growth turned out to be much higher in certain peripheral economies than in the core countries where it was developed. By contrast, in Uruguay the growth contribution of railways was substantially lower and not different from their role in the core countries. Therefore, despite its much higher railway density, Uruguay would join the ranks of those Latin American economies, such as Colombia or Peru, where the railway (although for different reasons) had a minor economic role during the first globalisation period. 


\section{CONCLUSIONS}

Railways constituted one of the most important technological breakthroughs of the $20^{\text {th }}$ century, leading to a substantial upward shift in national economies' production functions worldwide. In the case of Latin America, historians have often highlighted the importance of railways for export expansion and economic growth during the first globalisation boom. The social saving literature has also given empirical support to the hypothesis that those Latin American countries that invested heavily in railways obtained higher benefits from them than the more developed economies of Europe or North America. In this context, this paper has provided estimates of the share that railways accounted for within economic growth in Argentina, Brazil, Mexico and Uruguay, which were among those Latin American economies that built relatively dense railway networks during the first globalisation boom. The results of the estimation indicate, first, that the contribution of railways to growth varied substantially across Latin America. More precisely, in the case of Uruguay, the railway growth contribution was very small, being actually lower than in some European countries, such as Britain and Spain. This result may be explained by the features of the Uruguayan geography and economic structure, and constitutes a warning against the generally accepted idea that railways provided higher benefits in Latin America than in the core industrialised countries.

By contrast, in the other three countries under study (Argentina, Mexico and Brazil) the growth contribution of railways was huge. In the first two countries, railways accounted for one-fifth to one-quarter of the total income per capita growth of the period under analysis. In the case of Brazil, the direct contribution of railways to growth was even higher, although this was a direct consequence of the stagnation and the huge geographical changes that affected the Brazilian economy throughout the period. These percentages are much larger than the equivalent figure in some European countries, such as Britain or Spain, and clearly indicate that an exceedingly large share of economic growth in these three economies was directly derived from the diffusion of railways during the first globalisation.

\section{REFERENCES}

Alliende Edwards, M. P. (1993): Historia del ferrocarril en Chile. Santiago: Pehuén Editores.

Bertino, M., and Tajam, H. (1999): El PBI de Uruguay, 1900-1955. Montevideo: Universidad de la República, Instituto de Economía.

Bértola, L. (1998): El PBI de Uruguay 1870-1936 y otras estimaciones. Montevideo: Universidad de la República, Facultad de Ciencias Sociales.

Bértola, L., and Ocampo, J. A. (2010): Desarrollo, vaivenes y desigualdad. Una historia económica de América Latina desde la independencia. Madrid: Secretaría General Iberoamericana. 
Bogart, D., and Chaudhary, L. (2012): «Engines of Growth: The Productivity Advance of Indian Railways, 1874-1912». Unpublished research paper.

Boyd, J. H., and Walton, G. M. (1972): «The Social Savings from Nineteenth-Century Rail Passenger Services». Explorations in Economic History 9 (3), pp. 233-254.

Caron, F. (1983): «France», in P. O’Brien (ed.), Railways and the Economic Growth of Western Europe. London: McMillan, pp. 28-48.

Contsworth, J. H. (1979): «Indispensable Railroads in a Backward Economy: The Case of Mexico». Journal of Economic History 39 (4), pp. 939-960.

Contsworth, J. H. (1981): Growth against Development: The Economic Impact of Railroads in Porfirian Mexico. DeKalb: Northern Illinois University Press.

Connolly, P. (1997): El contratista de don Porfirio. Obras públicas, deuda y desarrollo regional. Zamora: Colegio de Michoacán.

Cortés Conde, R. (1975): «Tendencias en la evolución de los salarios reales en Argentina, 1880-1910. Resultados preliminares». Instituto Torcuato Di Tella, Centro de Investigaciones Económicas, working paper.

Contés Conde, R. (1979): El progreso argentino, 1880-1914. Buenos Aires: Editorial Sudamericana.

Crafts, N. F. R. (2004a): «Social Savings as a Measure of the Contribution of a New Technology to Economic Growth». LSE, Department of Economic History Working Paper 06/04.

Crafts, N. F. R. (2004b): «Steam as a General Purpose Technology: A Growth Accounting Perspective». Economic Journal 114 (495), pp. 338-351.

CRAFTS, N. F. R. (2010): «The Contribution of New Technology to Economic Growth: Lessons from Economic History». Revista de Historia Económica-Journal of Iberian and Latin American Economic History 28 (3), pp. 409-440.

Della Paolera, G.; Taylor, A. M., and Bózzoli, C. G. (2003): «Historical Statistics», in G. Della Paolera and A. M. Taylor (eds), A New Economic History of Argentina. Cambridge: Cambridge University Press, pp. 376-385.

Dobado, R., and Marrero, G. A. (2005): «Corn Market Integration in Porfirian Mexico». Journal of Economic History 65 (1), pp. 103-128.

Ferreres, O. (2005): Dos siglos de economía argentina. Historia argentina en cifras. Buenos Aires: Ed. El Ateneo.

Fishlow, A. (1965): American Railroads and the Transformation of the Ante-bellum Economy. Cambridge, MA: Harvard University Press.

Flandreau, M., and Zumer, F. (2004): The Making of Global Finance, 1880-1913. Paris: OECD.

Fogel, R. W. (1964): Railroads and American Economic Growth: Essays in Econometric History. Baltimore: John Hopkins Press.

Fogel, R. W. (1979): «Notes on the Social Saving Controversy». Journal of Economic History 39 (1), pp. 1-54.

Goldsmith, R. (1986): Brasil 1850-1984: desenvolvimento financeiro sob um século de inflação. São Paulo: Harper \& Row do Brasil.

Grunstein Dickter, A. (1996): «¿Competencia o monopolio? Regulación y desarrollo ferrocarrilero en México, 1885-1911», in S. Kuntz Ficker and P. Riguzzi (eds), Ferrocarriles y vida económica en México (1850-1950). Del surgimiento tardío al decaimiento precoz. México: El Colegio Mexiquense, pp. 167-221.

Hausman, J. A. (1994): "Valuation of New Goods Under Perfect and Imperfect Competition». NBER Working Paper 4970.

Hawke, G. R. (1970): Railways and Economic Growth in England and Wales. Oxford: Clarendon Press. 
Herranz-Loncán, A. (2005): «The Spanish Infrastructure Stock, 1845-1935». Research in Economic History 23, pp. 85-129.

HerRanz-LonCÁn, A. (2006): «Railroad Impact in Backward Economies: Spain, 1850-1913». Journal of Economic History 66 (4), pp. 853-881.

Herranz-Loncán, A. (2008): Infraestructuras y crecimiento económico en España, 1850-1935. Madrid: Fundación de los Ferrocarriles Españoles.

Herranz-Loncán, A. (2011a): «El impacto directo del ferrocarril sobre el crecimiento económico argentino durante la Primera Globalización». Revista de la Asociación Uruguaya de Historia Económica 1 (1), pp. 34-52.

Herranz-Loncán, A. (2011b): "The Role of Railways in Export-Led Growth: the Case of Uruguay, 1870-1913». Economic History of Developing Regions 26 (2), pp. 1-32.

Herranz-Loncán, A., and Peres-Cajías, J. A. (2013), «Tracing the Reversal of Fortune in the Americas. Bolivian GDP Per Capita Since the Mid-Nineteenth Century». Unpublished research paper.

JARA-DíaZ, S. R. (1986): «On the Relation Between Users' Benefits and the Economic Effects of Transportation Activities». Journal of Regional Science 26 (2), pp. 379-391.

KunTz FickeR, S. (1995): "Mercado interno y vinculación con el exterior: el papel de los ferrocarriles en la economía del porfiriato». Historia Mexicana XLV (1), pp. 39-66.

KunTZ Ficker, S. (1999): «Los ferrocarriles y la formación del espacio económico en México, 1880-1910», in S. Kuntz Ficker and P. Connolly (coord.), Ferrocarriles y Obras Públicas. México: Instituto Mora, pp. 105-137.

Leunig, T. (2010): «Social Savings». Journal of Economic Surveys 24 (5), pp. 775-800.

Lewis, C. (1983): British Railways in Argentina, 1857-1914. London: Institute of Latin American Studies.

Maddison, A. (2001): The World Economy: A Millennial Perspective. Paris: OECD.

Marín Vicuña, S. (1901): Estudios de los ferrocarriles chilenos. Santiago: Imprenta Cervantes.

Metzer, J. (1977): Some Economic Aspects of Railroad Development in Tsarist Russia. New York: Arno Press.

Metzer, J. (1984): «Railroads and the Efficiency of Internal Markets: Some Conceptual and Practical Considerations». Economic Development and Cultural Change 33 (1), pp. 61-70.

Mitchell, B. R. (2003): International Historical Statistics: The Americas, 1750-2000. Houndmills: Palgrave.

O'BRIEN, P. (1983): «Transport and Economic Development in Europe, 1789-1914», in P. O'Brien (ed.), Railways and the Economic Growth of Western Europe. London: McMillan, pp. 1-27.

Oliner, S. D., and Sichel, D. E. (2002): «Information Technology and Productivity: Where Are We Now and Where Are We Going». Federal Reserve Bank of Atlanta Economic Review 87 (3), pp. 15-44.

Ortiz Hernán, S. (1996): "Introducción», in S. Kuntz Ficker and P. Riguzzi (eds), Ferrocarriles y vida económica en México (1850-1950). Del surgimiento tardío al decaimiento precoz. México: El Colegio Mexiquense, pp. 15-30.

Prados De La Escosura, L. (2009): «Lost Decades? Economic Performance in PostIndependence Latin America». Journal of Latin American Studies 41 (2), pp. 279-307.

Ramírez, M. T. (2001): «Los ferrocarriles y su impacto sobre la economía colombiana». Revista de Historia Económica 19 (1), pp. 81-122.

SANZ FERnándeZ, J. (coord.) (1998): Historia de los ferrocarriles de Iberoamérica (1837-1995). Madrid: Ministerio de Fomento. 
Summerhill, W. R. (2000). «Profit and Productivity on Argentine Railroads, 1857-1913». Unpublished research paper.

Summerhill, W. R. (2003): Order Against Progress. Government, Foreign Investment, and Railroads in Brazil, 1854-1913. Stanford: Stanford University Press.

SummerhiLl, W. R. (2005): «Big Social Savings in a Small Laggard Economy: Railroad-Led Growth in Brazil». Journal of Economic History 65 (1), pp. 72-102.

Summerhill, W. R. (2006): «The Development of Infrastructure», in V. Bulmer-Thomas, J. Coatsworth and R. Cortés Conde (eds), The Cambridge Economic History of Latin America. Vol. 2: The Long Twentieth Century. Cambridge: Cambridge University Press, pp. 293-326.

VÁzouez-PRESEdo, V. (1971): Estadísticas históricas argentinas (comparadas). Primera parte 1875-1914. Buenos Aires: Ediciones Macchi.

Yáñez, C., Rivero, R., Badia-Miró, M., and Carreras-Marín, A. (2012): «La población de los países latinoamericanos desde el siglo XIX hasta el 2008. Ensayo de historia cuantitativa». DT-AEHE No. 2012.

ZEgARRA, L. F. (2013): «Transportation Costs and the Social Savings of Railroads in Latin America. The Case of Peru». Revista de Historia Económica-Journal of Iberian and Latin American Economic History, 31 (1), pp. 41-72. 